\title{
Reading and Theorizing James Baldwin: A Bibliographic Essay
}

\author{
Conseula Francis College of Charleston, South Carolina
}

\begin{abstract}
Readers and critics alike, for the past sixty years, generally agree that Baldwin is a major African-American writer. What they do not agree on is why. Because of his artistic and intellectual complexity, Baldwin's work resists easy categorization and Baldwin scholarship, consequently, spans the critical horizon. This essay provides an overview of the three major periods of Baldwin scholarship. 1963-73 is a period that begins with the publication of The Fire Next Time and sees Baldwin grace the cover of Time magazine. This period ends with Time declaring Baldwin too passé to publish an interview with him and with critics questioning his relevance. The second period, 1974-87, finds critics attempting to rehabilitate Baldwin's reputation and work, especially as scholars begin to codify the African-American literary canon in anthologies and American universities. Finally, scholarship in the period after Baldwin's death takes the opportunity to challenge common assumptions and silences surrounding Baldwin's work. Armed with the methodologies of cultural studies and the critical insights of queer theory, critics set the stage for the current Baldwin renaissance.
\end{abstract}

Keywords: James Baldwin, critical reception, literary history, literary criticism, African-American literature

Considering the critical reception of James Baldwin is difficult for a number of reasons. First, Baldwin was a widely reviewed, widely studied, prolific author. He published twenty-two full-length works in his lifetime, in addition to many essays, reviews, introductions, and interviews. In addition, his career was quite long. He made his mark on the literary scene in 1949 with his essay "Everybody's Protest Novel" and published a long essay on the Atlanta child murders and a retrospective collection of his essays in 1985. As a result of this long and prolific career, Baldwin's work experiences numerous waves of being in and out 
of vogue, making it difficult to ascertain which critical trends are significant in Baldwin scholarship and which are merely the result of critical fashion.

Another difficulty in studying the critical reception of Baldwin is that so many critical, political, ideological, and identity groups lay claim to him that it is almost impossible to find a critical center in Baldwin scholarship. Studying the last fifty years of Baldwin scholarship means engaging feminist and queer theory; it means considering the critical backlash against black nationalist politics; it means looking at the tradition of black American writing both inside and outside the United States; it means wading into a critical pool that is as interested in his sexuality as it is his gender and nationality and religion and taste in film. Yet it is for all these reasons that taking stock of half a century of Baldwin criticism is also a very exciting task. Making sense of the contradictions, accounting for the absences, shedding light on the controversies, and taking stock of the trends allows us to consider Baldwin's work in a new light.

What follows are highlights from what I've identified as the three major periods of Baldwin scholarship. ${ }^{1} 1963-73$ is a period that begins with the publication of The Fire Next Time and sees Baldwin grace the cover of Time magazine. This period ends with Time declaring Baldwin too passé to publish an interview with him and with critics questioning his relevance. The second period, 1974-87, finds critics attempting to rehabilitate Baldwin's reputation and work, especially as scholars begin to codify the African-American literary canon in anthologies and American universities. Finally, scholarship in the period after Baldwin's death takes the opportunity to challenge common assumptions and silences surrounding Baldwin's work. Armed with the methodologies of cultural studies and the critical insights of queer theory, critics set the stage for the current Baldwin renaissance.

\section{3-73}

During this period, critics seem most interested in appraising Baldwin's work and career. The question many seem to ask, both implicitly and explicitly, is whether or not Baldwin is a worthy successor to Richard Wright's literary throne. This is especially true of the three essays that anchor this period as touchstones of Baldwin scholarship: Irving Howe's "Black Boys and Native Sons" (1963); Robert Bone's “The Novels of James Baldwin" (1965); and Eldridge Cleaver's "Notes on a Native Son" (1968). While contemporary scholarship invokes these essays primarily to challenge the dubious assertions made about Baldwin and his work, the fact that nearly fifty years later critics still feel it necessary to engage their arguments speaks to the critical sway Howe, Bone, and Cleaver have held over Baldwin scholarship.

Howe, founding editor of Dissent and famed New York intellectual, published "Black Boys and Native Sons" in Dissent in Autumn 1963, shortly after 
the publication of The Fire Next Time. To Howe's credit, I think he genuinely intends to do the work of the critic-assess the aesthetic value/accomplishment of Baldwin's (and, to a lesser extent, Ralph Ellison's) work. The first paragraph gives a fairly accurate summary of Baldwin-on-Wright and it seems as if Howe is going to engage Baldwin's ideas about the "failure of the protest novel." While generally dismissive of Baldwin's criticism of protest, likening it to the "attacks launched by young writers against their famous fathers" as "a kind of announcement of [their] intentions," 2 Howe nonetheless makes a good point.

If it is true, as Baldwin said in "Everybody's Protest Novel," that "literature and sociology are not one and the same," it is equally true that such statements hardly begin to cope with the problem of how a writer's own experience affects his desire to represent human affairs in a work of fiction. Baldwin's formula evades, through rhetorical sweep, the genuinely difficult issue of the relationship between social experience and literature. ${ }^{3}$

Perhaps Baldwin doesn't, in fact, allow that it is difficult to keep one's experience from shaping one's art, or relatedly, that Wright's experience could have resulted in nothing other than Bigger Thomas. Perhaps, Howe seems to imply here, Wright's "social experience" of Mississippi is different from Baldwin's experience of Harlem, and we can't easily dismiss those differences in experience when studying the literature they give rise to. Consequently the reader expects further explication of this idea and expects that Howe will provide a new defense of the Wright school of protest. Instead, we get a definition of art that forgives the black writer for producing bad books and a backhanded compliment for Baldwin's work.

Howe clearly thinks of Wright as the epitome of the black spokesman, by which he means the black writer who translates the black experience for white America. His greatest strength as a writer, at least according to Howe, is his willingness to embrace the rage engendered by the black male existence (Native Son is, by all accounts, a violent, angry novel). Howe writes:

In all its crudeness, melodrama and claustrophobia of vision, Richard Wright's novel brought out into the open, as no one ever had before, the hatred, fear and violence that have crippled and may yet destroy our culture.... Wright forced his readers to acknowledge his anger, and in that way, if none other, he wrested for himself a sense of dignity, as a man. ${ }^{4}$

Howe assumes that Baldwin and Ellison fail to see the dignity of Wright's anger and views this rejection of Wright's form of protest, literary naturalism, as a betrayal. These two "native sons" fail as spokesmen, according to Howe, when they reject the "black boy" that is Wright. 
Howe goes on to say, "If such younger novelists as Baldwin and Ralph Ellison were able to move beyond Wright's harsh naturalism and toward more supple modes of fiction, that was possible only because Wright had been there first, courageous enough to release the full weight of his anger." And while Howe acknowledges that Baldwin may have a point about the burden of the "full weight of anger," he nevertheless defends the role of spokesman: "All one can ask, by way of reply, is whether the refusal to struggle may not exact a still greater price." And it is this sympathy for the struggle that ultimately leads Howe, despite his criticisms, to defend Baldwin against charges that his tone, with the publication of The Fire Next Time, had become too strident.

Howe asserts that Baldwin, by 1963, had finally, if belatedly, given in to the "blackness" of his experience, which he can't help but express in Wright-like terms.

He wanted to move, as Wright had not been able to, beyond the burden or bravado of his stigma; he wanted to enter the world of freedom, grace, and self-creation. One would need a heart of stone, or to be a brutal moralist, to feel anything but sympathy for this desire. But we do not make our circumstances; we can, at best, try to remake them. And all the recent writing of Baldwin indicates that the wishes of youth could not be realized, not in this country. The sentiments of humanity which had made him rebel against Richard Wright have now driven him back to a position close to Wright's rebellion. ${ }^{7}$

According to Howe, evidence of this rebellion can be seen in The Fire Next Time and Baldwin's essays on Harlem and the South, essays that "gain at least some of their resonance from the tone of unrelenting protest in which they are written, from the very anger, even the violence Baldwin had begun by rejecting.... Like Richard Wright before him, Baldwin has discovered that to assert his humanity he must release his rage." 8 Here Howe suggests that if Baldwin (and, to some extent, Ellison) actually did move African-American literature in a new direction, it was only to find that the old path, the path of Wright-ian protest, is the most useful in writing about black life.

Howe's essay remains significant for a couple of reasons. First, it occasions a very famous response from Ralph Ellison, in the essay "The World and the Jug," who says that Howe sees in the black man "not a human being but an abstract embodiment of living hell." Second, it is one of the first in a flurry of critical essays during this era examining the so-called Wright/Baldwin debate. This debate, consisting of three essays by Baldwin ("Everybody's Protest Novel," "Many Thousands Gone" in 1951, and "Alas, Poor Richard" in 1961) and a few comments by Wright, was rehashed by numerous critics at this time, ${ }^{10}$ in part because, like Howe, they were reacting to Wright's death in 1960. Baldwin, typically, comes up short in these comparisons, as he does in Cleaver's Soul on Ice.

Cleaver was among Baldwin's harshest critics. His "Notes on a Native Son" is notorious for its outrageous homophobic attack on Baldwin. Indeed, this essay becomes a touchstone for queer theory scholars who take up Baldwin's work after 
his death. The essay starts off innocently enough, with Cleaver praising Baldwin's genius (a familiar move in Baldwin criticism of this period):

After reading a couple of James Baldwin's books, I began experiencing that continuous delight one feels upon discovering a fascinating, brilliant talent on the scene, a talent capable of penetrating so profoundly into one's own little world that one knows oneself to have been unalterably changed and liberated, liberated from the frustrating grasp of whatever devils happen to possess one. ${ }^{11}$

This clever rhetorical move makes the rest of the essay that much more damning. Cleaver is nothing short of reverent in this passage, so we are sympathetic when, upon closer inspection of Baldwin's work, particularly Another Country, Cleaver comes to the following conclusion: "There is in James Baldwin's work the most grueling, agonizing, total hatred of the blacks, particularly of himself, and the most shameful, fanatical, fawning, sycophantic love of the whites that one can find in the writings of any black American writer of note in our time."12

Leaving aside for the moment the incredibly facile reading of Baldwin Cleaver offers here, at the heart of this statement is a common criticism of Baldwin lodged by African-American readers and critics at the time. Many felt that Baldwin talked too eagerly and too exclusively to white America, and thus could be of no real use to black people (not Negroes or colored) in need of a revolution. Cleaver may have a good point about Baldwin's relevance, about his ability to speak truthfully about black experience to white people, about the usefulness of that project, about the effect of Baldwin's celebrity on his work. However, he leaves this argument aside, choosing instead to pursue the issue of self-hatred of black homosexuals:

The white man has deprived him of his masculinity, castrated him in the center of his burning skull, and when he submits to this change and takes the white man for his lover as well as Big Daddy, he focuses on 'whiteness' all the love in his pent up soul and turns the razor edge of hatred against 'blackness'-upon himself, what he is, and all those who look like him, remind him of himself. He may even hate the darkness of night.... The racial death-wish is manifested as the driving force in James Baldwin. ${ }^{13}$

While Cleaver never actually identifies Baldwin as homosexual, the reader doesn't need much help making the connections Cleaver implies here. But just in case we need some help, Cleaver offers us the figure of Richard Wright to show us what a black male writer should be. He says of Wright, "Of all black American novelists, and indeed all American novelists of any hue, Richard Wright reigns supreme for his profound political, economic, and social reference." ${ }^{14}$ As an added bonus, all the men in Wright's work are "strongly heterosexual."15 The same cannot be said for Baldwin's characters, or, by implication, of Baldwin.

While Baldwin certainly didn't identify as "gay" or live his life "out" in the way we think of these terms post-Stonewall, neither did he hide is relationships 
with men. And while Cleaver doesn't exactly "out” Baldwin in this essay, his intent is clear.

The case of James Baldwin aside for the moment, it seems that many Negro homosexuals, acquiescing in this racial death-wish, are outraged and frustrated because in their sickness they are unable to have a baby by a white man. The cross they have to bear is that, already bending over and touching their toes for the white man, the fruit of their miscegenation is not the little half-white offspring of their dreams but an increase in the unwinding of their nerves-though they redouble their efforts and intake of the white man's sperm. ${ }^{16}$

Beneath the surface of this homophobic rant, Cleaver is accusing Baldwin of failing as a black artist because he fails as a black man (which Cleaver can only speak about in the most vulgar, patriarchal, heterosexist terms). Coming on the heels of Baldwin's seeming transformation into a fiery black spokesman, Cleaver suggests that Baldwin's anger is impotent, not only because of its late arrival in The Fire Next Time, but also because, according to Cleaver, it is born not of genuine frustration and exhaustion with the American racial predicament (as is presumably the case with black nationalism), or of a sincere desire for racial revolution, but rather of a kind of heartbreak. Cleaver portrays Baldwin as a jilted lover, rejected and acting out in pain. Couple this with the emphasis on embodiment during the Black Power/Black Arts Movement (black male writers were supposed to swagger in person and in print) and we get a portrait of a decidedly counterrevolutionary Baldwin.

For Cleaver, the future of black America is at stake. In order for black people to survive the American racial onslaught, they must experience a shift in their collective consciousness, a shift that will be facilitated by the work of revolutionary artists. As Cleaver states, "We are engaging in the deepest, the most fundamental revolution and reconstruction which men have ever been called upon to make in their lives, and which they absolutely cannot escape or avoid except at the peril of the very continued existence of human life on this planet."17 Baldwin's homosexuality, in his work and in his life, makes him unsuited, according to Cleaver, to prepare black people for this "reconstruction." Cleaver does not "think homosexuality is the latest advance over heterosexuality on the scale of human evolution. Homosexuality is a sickness, just as are baby-rape or wanting to become head of General Motors." 18

Although Cleaver's essay sets the contours of the conversation (Baldwin is counterrevolutionary, Baldwin is only concerned with whites, Baldwin fails as a successor to Wright), other writers are more lucid and evenhanded in their criticism of Baldwin and their belief that his work is insufficient for the revolutionary cause. Critics like Larry Neal and J. Saunders Redding admire Baldwin's creative skill, but lament his inability and/or unwillingness to commit to the Black Revolution.

The last touchstone piece in this period, Robert Bone's chapter on Baldwin in his seminal critical work The Negro Novel in America (1958; revised, 1965), 
attempts to turn a serious, scholarly eye to the newly important Baldwin. Bone's aim in this book is corrective. He contends that most criticism treats the "Negro novel ... primarily as social documents, and [they are] 'evaluated' according to the social bias of the critic."19 Bone, instead, aims to offer "literary judgments," to "distinguish the peaks from the valleys, to determine which of these novels are worth remembering and which are best forgotten." 20 To do this he employs two concepts- "assimilationism and Negro nationalism"-because these concepts are "indispensable to understanding the cultural history of the American Negro." 21 Bone argues that recognizing that individual blacks as well as black culture/ history travel between these two poles will better allow critical (rather than ideological) engagement of the "Negro novel." While Bone considers Baldwin the "most important Negro writer to emerge during the last decade," 22 it is not clear if he considers Baldwin important because of his success, popularity, influence, or talent. He does make clear, though, that we can't let Baldwin's popularity blind us to the unevenness of his work. As critics, we must put popularity aside, no matter how difficult.

Because Bone's project is an examination of African-American fiction, he doesn't actually explore the anger of The Fire Next Time or Blues for Mister Charlie, popular works at the time. Instead he devotes all of his critical attention to the three novels that had been published up to that point: Go Tell It on the Mountain, Giovanni's Room, and Another Country. Once he moves beyond the discussion of the "overwhelming facts" of Baldwin's life, Bone gets down to what seems to interest him most, namely, what happens when Baldwin stops narrating the experience of rejection, shame, and the American race drama. True, Baldwin is certainly not the first to do this. As Bone acknowledges in earlier parts of his book, writers like Frank Yerby, Ann Petry, and Chester Himes all set aside the Negro milieu to write "raceless" novels. But Bone dismisses them as pulp writers or as assimilationists or as of interest only in establishing a tradition.

But Baldwin, in 1965, is famous and popular, and the public pays attention to what he writes. He is not so easy to dismiss, yet it seems at several points that Bone needs to remind us that Baldwin is off his game. This is especially true in his intensely homophobic reading of Another Country. Here he describes the action of the novel:

A Greenwich Village setting and a hipster idiom. A square thrown in for laughs. A good deal of boozing and an occasional stick of tea. Some male cheesecake. Five orgasms (two interracial and two homosexual) or approximately one per eighty pages, a significant increase over the Mailer rate. Distracted by this nonsense, how can one attend to the serious business of the novel? ${ }^{23}$

His tone suggests that we shouldn't take the novel seriously, nor, consequently, should we take its author seriously. Rather than living up to the promise we witness in the early essays and Go Tell It on the Mountain, we instead get a 
Baldwin in full sexual rebellion. Bone looks to the details of Baldwin's life to explain this rebellion. According to Bone, Baldwin's decline dates back to the moment his "dawning sensuality collided with his youthful ministry:"

At first he rebelled against the store-front church, then Harlem, seeking to escape at any cost. Ultimately he came to reject the female sex [the only overt mention of Baldwin's homosexuality], the white world, and the Christian God. As rebellion grew, he discovered in his gift of language a means of liberation. Like hundreds of American writers, he fled from the provinces (in his case, Harlem) to Greenwich Village and the Left Bank. There he hoped to find a haven of sexual, racial, and intellectual freedom.

He quickly discovered, however, that he had not left the Avenue behind. In Greenwich Village or its French equivalent, he peered into the abyss, the demimonde of gay bars, street boys, and male prostitutes. This he recognized as Hell and recoiled in horror. But what alternative does he offer to promiscuity and fleeting physical encounter? He speaks in the rhetoric of commitment and responsibility, but what he has in mind is simply a homosexual version of romantic love. It is a familiar spiritual maneuver. Baldwin has built a palace on the ramparts of Hell and called it Heaven. Its proper name is Pandemonium. ${ }^{24}$

The seeming rampant immorality and sexuality in Another Country and the overt (angry) politics of The Fire Next Time and Blues for Mister Charlie all suggest to Bone that Baldwin's rebellion is in full swing and that this is hurting his work: "[E]vil has become Baldwin's good. The loss of meaning that ensues is both moral and semantic, and the writer who permits it betrays both self and craft." 25

That Bone begins his essay on Baldwin dismissive of his popularity suggests that he, in part at least, blames that popularity for the decline of Baldwin's art. For Bone, Baldwin's fiction is uneven at best, artistically bankrupt at worst, and his skill and popularity as an essayist blinds us to this fact.

\section{4-87}

In 1973 Henry Louis Gates, Jr., future director of the W. E. B. Dubois Institute for African and African-American Research at Harvard, but then a Cambridge University graduate student and Time correspondent, planned an article on black expatriates. In August of that year he dined with Baldwin, Josephine Baker, and several others at Baldwin's French estate. While that evening would inspire Baldwin to write The Welcome Table, a play he completed just before his death, Time declined to publish Gates' interview, calling Baldwin "passé."26 By 1973 Baldwin had ceased to be America's brightest African-American literary star.

Consequently, one of the unstated goals of many of critics of this era of Baldwin scholarship seems to be the rehabilitation of Baldwin's literary image, achieved through sophisticated verbal analysis. Several critics and critical conversations stand out in this period. 
The first is Louis H. Pratt. Pratt begins his 1976 essay "James Baldwin and "The Literary Ghetto" by discussing critics who have ghetto-ized African-American literature, primarily by labeling it "protest literature." Protest, he argues, "is a designation reserved for literature written by black Americans, all of which is assumed to be a remonstration against the economic, social, and political condition of the black man in America. As a descriptive phrase, it becomes a literary innuendo which proclaims the inferiority and sterility of the Afro-American literary tradition." 27

Pratt takes the term "literary ghetto" from John A. Williams, who argues that critics "limit severely the expansion of the talents of Negro writers and confine them to a literary ghetto from which only one Negro name at a time may emerge." 28 This, of course, is precisely what happens in the criticism of the previous period. "The one" had been Wright, and many critics (Cleaver, Howe) weren't ready to relinquish that spot to Baldwin. And during this period other writersAmiri Baraka, Ishmael Reed, John Wideman and black women writers like Toni Morrison, Toni Cade Bambara, and Alice Walker-are jockeying for position.

Pratt argues that this literary ghetto "tends to be representative of a subtlymasked form of racism which functions to stifle and suppress black talent and confirms the myth that blacks are limited in their capacity to produce serious literature." 29 Recalling the tenor of much of the criticism of the last period, Pratt reminds us that many critics expect very little from the "limited capacity" of black writers, and work on the assumption that a preoccupation with race is the chief cause of that limitation. In Baldwin's case, with the publication of Fire, he gave up being a serious (universal) writer to be a political (black) writer. Pratt contends that critics come to this particular conclusion about Baldwin by focusing primarily on his essays, his most overtly political work. While critics in this period will try to remedy this misrepresentation of Baldwin's body of work often by ignoring the essays altogether (focusing instead on Baldwin's fiction and drama), Pratt argues that this only masks the problem. The problem is not the essays themselves, but rather our reading of them.

To prove his point, Pratt offers a close reading of a passage from Baldwin's essay "Fifth Avenue, Uptown," collected in Nobody Knows My Name (1961). Pratt argues that the repetitive subject-verb introductory sentence constructions form an "organic relationship" 30 with the essay's topic: the unfaltering conditions of black life and the people who persevere despite those conditions. $\mathrm{He}$ also highlights the sense of urgency and outrage created by the repetitive and short sentences in Baldwin's "To Be Baptized," collected in No Name in the Street (1972). Because the essay takes up the topic of justice or, rather, the lack thereof, for people of color in America, the simmering rage suggested by Baldwin's style forces the reader into a "confrontation with reality." 31 In other words, Baldwin doesn't rely simply on a recitation of facts or a catalog of grievances to elicit a response from his readers. Instead, he carefully crafts an artful essay that in form and content communicates Baldwin's thoughts on American racial politics. 
In many ways Pratt's argument recalls George Kent's 1964 essay "James Baldwin and the Problem of Being." Kent posited that if Baldwin's work suffered from anything, it was that he had yet to find the form that could adequately contain his prophetic ideas. Pratt's reply seems to be that Baldwin had indeed found his form, particularly in his non-fiction, but that form had been inadequately studied by critics. Indeed, the critics in the previous period demonstrate nicely the "literary ghetto" Pratt discussed in the beginning of his essay. Because those critics substituted "social for artistic criticism," assuming that the "power of fact [was] the motivating force in [Baldwin's] essays," Pratt contends, they miss the artfulness and, therefore, much of the power of those essays. ${ }^{32}$

He concludes his essay by issuing a challenge to other critics: "a brief and initial examination of the aesthetic basis of the essays such as this cannot be regarded as exhaustive. It is, nevertheless, an evaluation which critics thus far have not undertaken." ${ }^{33}$ In short, a formalist reading, one that pays no heed to racialized/racist assumptions about African-American literature, will get us to a better, more nuanced understanding of Baldwin's (and African-American literature's) genius. Rigorous scholarship can correct the critical missteps of the past. This period sees many critics taking up this call.

Another critic who stands out in this period is Emmanuel S. Nelson. Nelson, who will be at the forefront of "queering" Baldwin in the next period, here initiates a discussion of sexuality in Baldwin's work by arguing for its metaphorical nature, i.e. the particular (homo)sexuality of Baldwin's characters can be read as metaphors for the universal human condition. In "James Baldwin's Vision of Otherness and Community" (1983), Nelson argues that Baldwin has translated his own struggle for self, as a black and homosexual man, into fiction. For Nelson, the search for self is the central theme in Baldwin's work and Baldwin shows how difficult that search can be. Often we are uncomfortable with what we find when we look too closely within:

To Baldwin, personal as well as collective failures stem from the inability of individuals to confront the 'darker' sides of their human nature. Out of this failure comes the mechanism of scapegoating: racial and sexual minorities become visible symbols of the 'darker' side-the buried repressions, disturbing anxieties, and hidden pathologies—of the members of the Establishment majority. ${ }^{34}$

Baldwin's fiction is about these scapegoated racial and sexual minorities. Their suffering becomes instructive:

Suffering, if endured creatively, leads to self-knowledge, which, in return, can offer the possibility of achieving a genuine sense of self. Hence, suffering has humanizing power, and redemptive potential. If many of the Black characters in Baldwin's fiction are presented as morally superior to most of the white characters ... it is not because those characters are Black, but because their blackness inflicts additional suffering on them, suffering that can be uplifting and humanizing. ${ }^{35}$ 
By implication, the same is true of Baldwin's homosexual characters: "Hence, blackness and homosexuality in Baldwin's fiction assume metaphorical functions: they are both sources of agony as well as means of redemption; they bring suffering, but, if dealt with courageously, they can lead to self-knowledge, self-acceptance, and the forging of a genuine self-identity." ${ }^{36}$ Though Nelson will go on in later criticism to deal with homosexual characters as homosexual, here he seems to suggest that we understand Baldwin's fiction not as stories about black/gay identity, but rather as instructive of identity formation and that the particulars of his black/gay characters serve to highlight that process. While this move at times feels like an attempt to "save" Baldwin from blackness or nationalist politics, by focusing in on the particular details of Baldwin's plots, rather than simply generalities about race that can be gleaned from that work, Nelson opens the critical door to discuss topics other critics tended to avoid.

Significant in this period as well is the critical move to tackle perhaps the most significant theme in Baldwin's work: love. While I think that critics still have yet to sufficiently define or explicate Baldwin's "love," critics during this period offer compelling insights. In "The Dilemma of Love in Go Tell It on the Mountain and Giovanni's Room" (1974), George E. Bell defines the issue as the paradox that only love can save you in a world where there is only a limited possibility of love. Yet, Bell reads Baldwin as optimistic: "Love is an attainable goal. Love is possible if one is willing to live existentially, if one is willing to abandon the puritan mythology of man's corruption, of the body's evil, of the necessity of sin and guilt, and to live freely, unashamedly, and unselfishly as a trusting and committed person." $37 \mathrm{He}$ argues that Esther, Richard, Elizabeth, John, and Elisha from Go Tell It on the Mountain and Giovanni from Giovanni's Room provide answers to the dilemma of love.

His close readings are notable, in part, because he matter-of-factly acknowledges the homoerotic tension between Elisha and John (this will not become a widespread reading of these characters until the next critical period in Baldwin scholarship) and doesn't fret about the lack of black characters in Giovanni's Room (he is one of the few critics who doesn't think this lack notable). He contrasts the characters mentioned above, characters who can give and receive love, with those who cannot, primarily Gabriel in Go Tell It On the Mountain and David in Giovanni's Room. He concludes that both novels have a primarily pessimistic thrust: "Both novels hold that the path to love is full of theological and psychological pitfalls. Only by successfully overcoming a puritanical sense of evil and guilt can a man gain the release needed to attain a mature, committed, loving, and hence meaningful relationship with another person." ${ }^{38}$ Despite these pessimistic stories, though, Bell ultimately positions Baldwin as a hopeful writer, one who holds out for the possibility of love, of true human connection, despite the seemingly impossible odds.

Peter Bruck, on the other hand, isn't as optimistic. In "Dungeon and Salvation: Biblical Rhetoric in James Baldwin's Just Above My Head” (1984), he argues that Baldwin's enthusiastic reception in the 1960s made him a "pampered child 
of the white liberal establishment" 39 and that the "morally oriented nature of his writings, his commitment to a philosophy of inter-racial love seemed to be outdated in a time which witnessed the formation of the Black Power and Black Panther movements and increased interest in the teachings of ethnic separatism." 40

Rather than a belief in the power of love as Bell states, Bruck argues that in Baldwin's characterization of Arthur in Just Above My Head, the "pessimism here apparent reveals the deep resignation of an author who had once set out to proclaim the idea of brotherly love." 41 Bruck sees in this novel a Baldwin who has been broken and who has, perhaps, betrayed his own progressive politics.

More than any other work, Just Above My Head demonstrates that the author, who had set out "to shake up whites and wake up blacks," has now lost his political and linguistic orientation. This novel shows none of his former desire to enlighten, but rather declares that salvation is now only possible as an individual process and not as a political vision of the future. ${ }^{42}$

Bell's and Bruck's articles quite nicely demonstrate the primary contours of this corner of Baldwin scholarship. Critics continue to try to determine if Baldwin offers us love as hopeful and redemptive, or if he reflects back to us a world in which love ultimately fails.

This period also sees the emergence of Trudier Harris as an important Baldwin scholar. Her two essays on Baldwin during this period-"The Eye as Weapon in If Beale Street Could Talk" (1978) and "The South as Woman: Chimeric Images of Emasculation in Just Above My Head" (1984) - not only treat works rarely ever discussed by other critics at this point, but also, without fanfare, contain the kind of close reading called for by other critics during this period. Harris's readings of Baldwin are notable because they are provocative. Her argument about Just Above My Head is that "If the South is painted in Baldwin's fiction as a female image which emasculates black men, and yet it is the males in that environment who most frequently carry out that gruesome emasculation, then the logical extension of the argument is that Southern white men are 'faggots.' Those who are without sexuality use the racial power they do have to acquire symbolically the manhood they have somehow lost." ${ }^{\prime 3}$ And she avoids the trap of nostalgia when reading Baldwin's later work. Of Beale Street she writes,

Baldwin has denuded his plot of the encumbrances that created problems for his characters in his earlier works. The major characters in Beale Street are not fanatically committed to organized religion and church affiliation. They are not subject to the torment of interracial sex/love relationships. They are not immobilized by involvement in homosexual affairs. They are just folks who love each other and who are committed to the human; however, it is the intensity of their concern for each other and the intense way Tish, with her central involvement in the story, to relate in her own creative, though unsophisticated way, Baldwin has made graceful simplicity the force or art. He has thereby moved his own creativity to a new level. ${ }^{44}$ 
By the time of James Baldwin's death from stomach cancer in 1987, there were several assumptions about James Baldwin and his work upon which most Baldwin scholarship was built. There was general agreement that he was an important African-American writer, though his relevance was primarily historical (i.e., he wrote several seminal essays that were important at a particular point in time). Critics generally agreed that his career peaked in the mid-1960s, and that while he excelled in the essay, with the exception of Go Tell It on the Mountain, he fell short in other genres. And finally, critics generally worked with the assumption that Baldwin spoke most passionately about race, downplayed his sexual orientation, and denounced Christianity.

\section{8-2000}

Critics during this period, having the benefit of being able to survey the entirety of Baldwin's career and as well the use of feminist, postmodern, cultural studies, and queer theory methodologies, attempt to challenge us to rethink what we knew and understood about Baldwin's work. This was done primarily by recontextualizing and queering Baldwin's work. Though other critical conversations are taking place (notably those about Henry James's influence on Baldwin, ${ }^{45}$ Baldwin's expatriation and his critical reception abroad, ${ }^{46}$ and the 40 th anniversary of Go Tell It on the Mountain), ${ }^{47}$ they don't lead to the same kind of broader reshaping of the critical terrain discussed below.

William J. Spurlin, in an article tracing the queer reception history of Baldwin, explains the critical space opened up by queer theory.

I must acknowledge that contemporary work in American lesbian and gay studies, academic queer theory, and post-Stonewall activism has enabled a space for me to (re)read the cultural lenses that helped interpret Baldwin and his work and constitute his reception in the early 1960s, and that my readings and critique of the claims made about homosexuality in the period under discussion make rhetorical use of queercentric interpretations of gay identity by these disciplines and social practices in the present. ${ }^{48}$

In other words, Spurlin can revisit Baldwin scholarship from earlier periods and address explicitly the homophobia informing that scholarship. Indeed, Eldridge Cleaver's and Robert Bone's critiques of Baldwin continue to resonate in part because they make such excellent fodder for queer theory.

One of the results of queer theory's influence on Baldwin scholarship is that it sheds new light on a popular Baldwin work, Go Tell It on the Mountain, and it brings oft-maligned work, like Giovanni's Room, to the center. In his "Critical Deviance: Homophobia and The Reception of James Baldwin's Fiction” (1991), for instance, Emmanuel S. Nelson calls Giovanni's Room "a classic work in modern gay fiction" $" 4$ and describes Go Tell It on the Mountain as a "complex 
text" that "offers one of the most poignant portrayals of developing adolescent homosexual consciousness in American fiction." 50

His readings of both novels stem from his desire to not limit Baldwin to being simply a gay or simply a black writer. "We have to explore the combined cultural, political and artistic consequences of both ... racial awareness and his homosexual consciousness on his literary imagination." ${ }^{11}$ The problem he sees in Baldwin scholarship has been an inability on the part of critics to deal adequately with the complexity of Baldwin's identity. "Many white critics are uncomfortable responding to a writer who is doubly different; many Black critics, though often enthusiastic about Baldwin's handling of racial themes, seem embarrassed and angered by his explicit treatment of homosexuality." 52 As a result, then, Nelson asserts a major aspect of Baldwin's work, his exploration of homosexuality and the influence of sexual identity on human society, gets lost in the critical shuffle.

Critics also return to religion in Baldwin's work. Notably in this period is “Just Above My Head: James Baldwin's Quest for Belief” by Michael F. Lynch (1997). While other critics have taken note of the religious aspects of Baldwin's work, most often tying religion to Baldwin's notion of love, none have, as Lynch does in his essay, posited a Baldwinian theology.

For Lynch the "most pervasive problem with Baldwin criticism is the projection of a dichotomized scheme onto an artist whose method is fundamentally dialectical."53 Here Lynch echoes Shelton Waldrep's 1994 assessment that Baldwin is a far more complicated writer than he is given credit for, but also echoes Addison Gayle's 1967 essay that urges us to recognize the dialectical nature of Baldwin's work. Like Gayle, Lynch recognizes that the critical tide turned against Baldwin after the publication of The Fire Next Time, when critics seemed to have decided that Baldwin had become too angry and too polemical:

But the inaccurate charge that he polemicizes his writing from that point on is rooted in critics' positing the political against the individual and/or spiritual, which opposition Baldwin attempts to reconcile. In my view, his middle and later work achieves more complex works of art than the prevailing assessment contends largely because he does not become a polemicist and because as a dialectical thinker he continues to respect and maintain the necessary vital tension between political reality and spiritual vision. ${ }^{54}$

Out of this dialectical thinking comes a theology that Lynch argues Baldwin "develops more as a corrective to than a repudiation of Christian theology as understood and practiced, and might be called 'radical' in the sense of being faithful to the spirit of the early church." 55 Baldwin's theology, he argues, "considers three complementary aspects of, or avenues toward, salvation: saving oneself through developing the ability to survive and to love, saving another through preferential or erotic love, and saving others through selfless action based on accepting responsibility for all people." ${ }^{26}$ Lynch then roots commonly 
discussed themes in Baldwin's work-eroticism and love-firmly in Baldwin's Christian faith. I find this reading particularly compelling not only because of the assumption of complexity in Baldwin's work (indeed, the notion of a Baldwinian theology developed in his novels demands further consideration), but also because Lynch refuses to throw out one Baldwin in order to privilege another. By assuming a complicated, dialectical Baldwin, Lynch creates a critical space where both Baldwinian eroticism and spirituality can live.

The most significant critical moves in this period, however, are made in the two groundbreaking anthologies that close out this period: James Baldwin Now (1999) and Re-Viewing James Baldwin: Things Not Seen (2000). Dwight A. McBride's introduction to James Baldwin Now asserts that this anthology offers "new ways of thinking about the life and work of James Baldwin, one of the most prolific and influential African-American writers ever to live, but also open[s] up new ways in which his work helps us understand many of our contemporary societal problems. ${ }^{n 7}$ What marks this anthology as different, the introduction goes on to state, is not simply what will be said about Baldwin, but also the who and how of the saying.

Written as they are by students and scholars who are still in the early stages of their careers, and who either were trained or are being trained in the academy during a time when interdisciplinary work and cultural studies are at what seems their nadir, these essays offer perspectives which are unique, in that they are not shackled by the traditional modes of conducting scholarship but rather are informed by a host of approaches that provide fresh, innovative analyzes, distinguishing themselves from much of the earlier work on Baldwin. ${ }^{58}$

Important here are the assertion of Baldwin's importance (particularly for a generation of scholars who know him primarily as an "important black writer" rather than those who remember him as an important political figure), his significance to a variety of different disciplines and identity groups (not all the critics are literary scholars; not all of them are black or gay or male), and the assertion that the scholarship that had come before was insufficient to the task of treating well Baldwin's complexity. Referring to previous critical treatment, McBride writes, "The fascination is with Baldwin's life, his presence, his political thought, as well as his work. This is evidenced by the paucity of real critical treatment of Baldwin's work in favor of the more biographical portraitures of the man. This book of essays represents a Baldwin revival of sorts" (8). And, finally, McBride asserts that we have only now arrived at the critical moment that can treat Baldwin in all his complexity: "With the advent of cultural studies, it is finally possible to understand Baldwin's vision of and for humanity in its complexity, locating him not as exclusively gay, black, expatriate, activist, or the like but as an intricately negotiated amalgam of all those things, which had to be constantly tailored to fit the circumstances in which he was compelled to articulate himself." ${ }^{\prime 9}$ 
Re-Viewing James Baldwin, edited by D. Quentin Miller, takes on a different, though equally significant, critical task. Miller notes in his introduction that writers are often known only for a small portion of their entire body of work and that this happens for a number of reasons. A work may be a prize-winning novel, or appear repeatedly on "top" and "best" lists. A particular work may be the favorite, for reasons unknown, of whimsical critics. Or a work may be chosen as "representative" of an author's career, and anthologized for use in courses, so that students encounter that same work over and over again. In the case of Baldwin, Miller contends, he falls out of favor in 1963 (after the publication of The Fire Next Time), resulting in a frozen image of a writer who expresses anger, frustration, and pain without making his (white, middle class) reading audience too uncomfortable. Consequently, "what has been lost is his trait of tremendously rich intellectual inquiry that illustrates the direction of African-American thought and culture in the late twentieth century. Also lost has been a widely varied oeuvre of an experimental writer who never was content with retelling the same story using the same voice, or speaking to the same audience. Lost, too, is the legacy of Baldwin's considerable influence." 60 This anthology, then, seeks to "examine works by Baldwin that have not received much critical attention in the past, approach some of his more canonical works from fresh critical perspectives, or both."

\section{A Baldwin Renaissance}

And so we return to the present. Twenty-first century Baldwin scholars explore and engage in the rich possibilities that come from understanding Baldwin and his work as belonging to multiple traditions, sometimes contradictorily, but always simultaneously. There is a great deal of work on Baldwin being published right now, creating a rich critical field in which to work. The diversity of work on Baldwin published in the last decade-notably work by Brian Norman, D. Quentin Miller, Magdalena Zaborowska, Randall Kenan, Lynn O. Scott, Douglas Field, Ed Pavlic, Matt Brim, and a recent issue of African American Review devoted to Baldwin-gives evidence of the enduring critical interest in Baldwin and his work. More importantly, these works suggest the direction Baldwin studies will take in the future-gone are articles that refute or reclaim Baldwin's blackness, that assert the relevance of his homosexuality (or attempt to deny it altogether), that defend or deride his spirituality, that celebrate him as an essayist and disparage him as a novelist, as we saw in early scholarship on his work. Instead, armed with critical tools from postmodernism, queer theory, and cultural studies, but also with a solid foundation in formalist criticism, contemporary critics seem eager to mine Baldwin's rich body of work for ever new insights and provocations. In current scholarship Baldwin assumes the role of a major African-American writer who is also a major gay writer, a prominent expatriate writer, a chronicler of American religion, and a window into mid-century politics and letters, among many other roles. Baldwin's work resonates with critics interested in African-American literature, gay literature, 
feminist criticism, religious studies, urban studies, expatriates, civil rights, politics, film criticism, and the role of the artist, to name only a few of the critical topics in Baldwin criticism. There are more monographs than ever specifically on Baldwin and his work, but also an increasing number of works in which Baldwin is merely one of many players in a critical conversation. He is being considered alongside his literary peers and progeny with greater regularity. Ultimately, there is no critical center in contemporary Baldwin scholarship, but this seems more than fitting for a writer who spent his entire career resisting easy answers and intellectual stagnation.

\section{Notes}

1 My book The Critical Reception of James Baldwin, 1963-2010 covers these periods in greater detail. In addition I discuss two important critical conversations not covered here: the scholarship on "Sonny's Blues," which exists almost wholly separate from other Baldwin criticism, and the extensive critical conversation in the popular reviews of Baldwin's work.

2 Irving Howe, "Black Boys and Native Sons," in Donald Gibson (ed.), Five Black Writers: Essays on Wright, Ellison, Baldwin, Hughes, and LeRoi Jones (New York, NYU Press, 1970), p. 255.

3 Ibid., p. 255.

4 Ibid., p. 256.

5 Ibid.

6 Ibid., p. 262.

7 Ibid., p. 268.

8 Ibid., p. 270.

9 Ralph Ellison, “Richard Wright's Blues," in John F. Callahan (ed.), The Collected Essays of Ralph Ellison (New York, Modern Library, 2003), p. 159.

10 See Maurice Charney's “James Baldwin’s Quarrel with Richard Wright,” (1963); J. Saunders Redding in "Since Richard Wright;" Albert Murray's "Something Different, Something More;" Nathan Scott's "Judgment Marked by a Cellar: The American Negro Writer and the Dialectic of Despair;" Donald B. Gibson's "Wright's Invisible Native Son;” B. K. Mitra's “The Wright-Baldwin Controversy;” Morris Dickstein's "Wright, Baldwin, Cleaver;" and Jerry H. Bryant's "Wright, Ellison, Baldwin-Exorcising the Demon."

11 Eldridge Cleaver, Soul on Ice (New York, McGraw-Hill, 1968), p. 97.

12 Ibid., p. 99.

13 Ibid., p. 103.

14 Ibid., p. 108.

15 Ibid., p. 106.

16 Ibid., p. 102.

17 Ibid., p. 110.

18 Ibid.

19 Robert Bone, The Negro Novel in America (New Haven, Yale UP, 1958; rev. ed. 1965), p. 7.

20 Ibid., p. 8.

21 Ibid., p. 7. 
22 Ibid., p. 215.

23 Ibid., p. 230.

24 Ibid., p. 237.

25 Ibid., p. 25.

26 David Adams Leeming, James Baldwin: A Biography (New York, Knopf, 1994), p. 320.

27 Louis Pratt, "James Baldwin and 'The Literary Ghetto," College Language Journal, 20 (1976), p. 265.

28 Ibid., p. 262.

29 Ibid., pp. 263-4.

30 Ibid., p. 268.

31 Ibid., p. 269.

32 Ibid., p. 268.

33 Ibid., p. 271.

34 Emmanuel Nelson, "James Baldwin's Vision of Otherness and Community," MELUS, 10 (1983), p. 27.

35 Ibid., pp. 27-8.

36 Ibid., p. 28.

37 George Bell, "The Dilemma of Love in Go Tell It on the Mountain and Giovanni's Room," College Language Association Journal, 17 (1974), p. 397, original emphasis.

38 Ibid., p. 406.

39 Peter Bruck, "Dungeon and Salvation: Biblical Rhetoric in James Baldwin's Just Above My Head," in Gunter H. Lenz (ed.), History and Tradition in Afro-American Culture (Frankfurt, Campus, 1984), p. 130.

40 Ibid., p. 131.

41 Ibid., p. 140.

42 Ibid., p. 142.

43 Trudier Harris, "The South as Woman: Chimeric Images of Emasculation in Just Above My Head," in Chester B. Fontenot (ed.), Studies in Black American Literature Volume I: Black American Prose Theory (Greenwood, F.L., Penkevill, 1984), p. 108.

44 Trudier Harris, "The Eyes as Weapon in If Beale Street Could Talk," MELUS, 5 (1978), p. 66.

45 See, especially, Horace A. Porter's Stealing Fire: The Art and Protest of James Baldwin (1989), a work that attempts a "reinterpretation of James Baldwin's genesis as a writer" by examining the influence of Richard Wright, Harriet Beecher Stowe, and Henry James on Baldwin's early work.

46 See James Baldwin: His Place in American Literary History and His Reception in Europe, in Jakob Köllhofer (ed.), (Frankfurt, Peter Lang, 1991); and The Critical Reception of James Baldwin in France by Rosa Bobia (New York, Peter Lang, 1997).

47 See New Essays on Go Tell It On a Mountain, in Trudier Harris (ed.), (New York, Cambridge University Press, 1996).

48 William Spurlin, "Transgressing Boundaries: James Baldwin and the Identity Politics of Race and Sexuality," in Lesley Marx, Loes Nas and Lara Dunwell (eds.), Fissions and Fusions: Proceedings of the First Conference of the Cape American Studies Association (Cape Town, University of the Western Cape Press, 1997), p. 47.

49 Emmanuel Nelson, "Critical Deviance: Homophobia and the Reception of James Baldwin's Fiction," Journal of American Culture, 14 (1991), p. 92.

50 Ibid., pp. 94-5.

51 Ibid., p. 91. 
52 Ibid., p. 92.

53 Michael Lynch, “Just Above My Head: James Baldwin’s Quest for Belief," Literature and Theology, 11 (1997), p. 285.

54 Ibid.

55 Ibid., p. 292.

56 Ibid., p. 293.

57 Dwight A. McBride (ed.), James Baldwin Now (New York, New York University Press, 1999), p. 1.

58 Ibid.

59 Ibid., p. 2.

60 D. Quentin Miller, Re-Viewing James Baldwin: Things Not Seen (Philadelphia, Temple University Press, 2000), pp. 2-3.

61 Ibid., p. 8.

\section{Works Cited}

Bell, George E., “The Dilemma of Love in Go Tell It on the Mountain and Giovanni's Room," College Language Association Journal, 17 (1974), pp. 397-406.

Bobia, Rosa, The Critical Reception of James Baldwin in France (New York, Peter Lang, 1997).

Bone, Robert, The Negro Novel in America, (1958) Revised edition, (New Haven, Yale University Press, 1965).

Bruck, Peter, "Dungeon and Salvation: Biblical Rhetoric in James Baldwin's Just Above My Head," in Gunter H. Lenz (ed.), History and Tradition in Afro-American Culture (Frankfurt, Campus, 1984), pp. 130-46.

Bryant, Jerry H., "Wright, Ellison, Baldwin-Exorcising the Demon," Phylon, 37:1 (1976), pp. 174-88.

Charney, Maurice, “James Baldwin's Quarrel with Richard Wright," American Quarterly, 15 (1963), pp. 65-75.

Cleaver, Eldridge, "Notes on a Native Son," Soul on Ice (New York, McGraw-Hill, 1968), pp. 122-37.

Dickstein, Morris, "Wright, Baldwin, Cleaver," New Letters, 38:2 (1971), pp. 117-24.

Ellison, Ralph, "Richard Wright's Blues," in John F. Callahan (ed.), The Collected Essays of Ralph Ellison (New York, Modern Library, 2003), pp. 128-44.

Gayle, Addison, Jr., "The Dialectic of The Fire Next Time," Negro History Bulletin, 30 (1967), pp. 15-16.

Gibson, Donald B., "Wright's Invisible Native Son,” American Quarterly, 21 (1969), pp. 728-38.

Harris, Trudier, "The Eyes as Weapon in If Beale Street Could Talk," MELUS, 5 (1978), pp. 54-66.

"The South as Woman: Chimeric Images of Emasculation in Just Above My Head," in Chester B. Fontenot (ed.), Studies in Black American Literature Volume I: Black American Prose Theory (Greenwood, F.L., Penkevill, 1984), pp. 89-109.

- (ed.), New Essays on Go Tell It on the Mountain (New York, Cambridge University Press, 1996).

Howe, Irving, "Black Boys and Native Sons," in Donald Gibson (ed.), Five Black Writers: Essays on Wright, Ellison, Baldwin, Hughes, and LeRoi Jones (New York, New York University Press, 1970), pp. 254-70. 
Kent, George E., "Baldwin and the Problem of Being," College Language Association Journal 7 (1964), pp. 202-14.

Köllhofer, Jakob, (ed.), James Baldwin: His Place in American Literary History and His Reception in Europe (Frankfurt, Peter Lang, 1991).

Leeming, David Adams, James Baldwin: A Biography (New York, Knopf, 1994).

Lynch, Michael F., "Just Above My Head: James Baldwin's Quest for Belief," Literature and Theology, 11 (1997), pp. 284-98.

McBride, Dwight A., (ed.), James Baldwin Now (New York, New York University Press, 1999).

Miller, D. Quentin, (ed.), Re-Viewing James Baldwin: Things Not Seen (Philadelphia, Temple University Press, 2000).

Mitra, B. K., "The Wright-Baldwin Controversy," The Indian Journal of American Studies, 1 (1969), pp. 101-5.

Murray, Albert, "Something Different, Something More," in Hill, Herbert (ed.), Anger and Beyond: The Negro Writer in the United States (New York, Harper \& Row, 1966), pp. 112-37.

Neal, Larry, “The Black Writer's Role, III: James Baldwin,” in Michael Schwartz (ed.), Visions of a Liberated Future: Black Arts Movement Writings (New York, Thunder's Mouth Press, 1989).

Nelson, Emmanuel S., "James Baldwin's Vision of Otherness and Community," MELUS, 10 (1983), pp. 27-31.

"Critical Deviance: Homophobia and the Reception of James Baldwin's Fiction," Journal of American Culture, 14 (1991), pp. 91-6.

Porter, Horace A., Stealing the Fire: The Art and Protest of James Baldwin (New York, Wesleyan University Press, 1989).

Pratt, Louis, "James Baldwin and 'The Literary Ghetto," College Language Journal, 20 (1976), pp. 262-72.

_ James Baldwin (Boston, Twayne Publishers, 1978).

Redding, Saunders, "Since Richard Wright," African Forum, 1 (1966), pp. 21-31.

Scott, Nathan O., Jr., "Judgment Marked by a Cellar: The American Negro Writer and the Dialectic of Despair," Denver Quarterly, 2 (1967), pp. 5-35.

Spurlin, William J., "Transgressing Boundaries: James Baldwin and the Identity Politics of Race and Sexuality," in Lesley Marx, Loes Nas and Lara Dunwell (eds.), Fissions and Fusions: Proceedings of the First Conference of the Cape American Studies Association (Cape Town, University of the Western Cape Press, 1997), pp. 46-55.

\section{Contributor's Biography}

Conseula Francis is professor of English and director of African-American Studies at the College of Charleston in South Carolina, where she teaches courses in African-American literature. She is the author of The Critical Reception of James Baldwin, 1963-2010 (Camden House, 2014) and editor of Conversations with Octavia Butler (Mississippi, 2009). Her current scholarship focuses on the radical black feminism of contemporary African-American romance and erotic fiction. 